\title{
A Sample Application for Use of Biography in Social Studies; Science, Technology and Social Change Course
}

\author{
Harun Er \\ Correspondence: Harun Er, Bartın University, Faculty of Education, Social Studies Education, 74100 Bartın, Turkey.
}

Received: March 16, 2017

doi:10.11114/jets.v5i5.2276

\author{
Accepted: April 14, $2017 \quad$ Online Published: April 23, 2017 \\ URL: https://doi.org/10.11114/jets.v5i5.2276
}

\begin{abstract}
The aim of this study is to evaluate the opinions of social studies teacher candidates on use of biography in science, technology and social change course given in the undergraduate program of social studies education. In this regard, convergent parallel design as a mixed research pattern was used to make use of both qualitative and quantitative data. A single-group pretest-posttest experimental pattern and a semi-structured interview form with three sections were used respectively for quantitative and qualitative data. The study group consists of 49 students receiving undergraduate education in the 2nd grade of Bartın University Faculty of Education Department of Primary Education - Social Studies Teaching. From quantitative point of view, a statistically significant difference was observed between the pretest and posttest results of the performed application. On the basis of gender variable, no significant difference was found between the opinions of male and female students on use of biography in science, technology and social change course. Qualitative results of the application indicate that the use of biography makes a positive contribution to the course, increases the level of permanent learning, and helps to teach the course materials in a more entertaining and attractive way, while limitations such as the questionable objectivity of references also exist, in addition to other issues such as availability of visuals and works.
\end{abstract}

Keywords: social studies, science, technology and social change, use of biography

\section{Introduction}

Education can be defined as lifelong acquisition of all kinds of knowledge, skills, and values needed by individuals throughout their lives. The main function of education is to raise individuals with physical and mental health, environmental awareness and the motivation to be useful to society. This can be achieved through establishment of a systematic and individual-centered concept of education. Primary and secondary school periods are the most important steps of education in which such concept of education is adopted and provided at the highest level. In this context, this period has critical importance for individuals in terms of receiving education in line with their interests and skills and preparing for the next level of education and life (Gültekin, 1999).

Social studies courses have particular importance in terms of providing the individuals in primary and secondary school age with an insight into life, and equipping them with desired skills and behaviors (Er, 2010). The main goal of social studies teaching is to provide citizens with critical thinking, awareness regarding their rights and responsibilities, and the ability to make good and sound decisions (Barth \& Demirtaş, 1997). In social studies courses, individuals find the opportunity to learn about their immediate and distant environment along with their past, present and future. In this regard, these courses have a critical function in establishment and development of personalities with high environmental and social awareness (Can, Yaşar \& Sözer, 1998).

Social studies courses inherently feature a multidisciplinary structure that embodies various topics such as history, geography, political sciences and citizenship (Yeşilbursa \& Sabanc1, 2015). The content of social studies courses have been addressed with an interdisciplinary approach and within the frame of integration (Öztürk, 2007). Accordingly, the courses require a wide variety of teaching materials that provide a solid understanding, facilitate learning, increase permanence and promote learning by experience (Oruç \& Erdem, 2010). Literary works are among the teaching materials which are qualified to respond these very needs.

Different types of literary works hold rich potential as important teaching materials in social studies courses. The strong relationship between literature and social studies have been commonly emphasized in recent studies, along with the need to support these courses with literary works such as novels, mythology, biography and drama (McGowan \& 
Guzzetti, 2003). Fredericks (2007) set forth the idea that the use of literary works can facilitate the achievement of objectives defined in the social studies programs, and according to Demir \& Akengin (2011), the presence of a close relationship between literary works and the impression left by the objectives of social studies courses on students, is very likely.

Biographies, in which life stories of individuals are told, can be regarded as effective teaching materials that can be used in social studies course contents (Öztürk \& Otluoğlu, 2003). The word biography originates from "bios" (liveliness, life) and "graphe" (script, form) and represents the texts written to tell the life stories of people (Taşdelen, 2006). According to Parke (1996), biographies are, in a sense, narratives of lives of people by which reaching beyond the limited course of human lives is aimed. Oğuzkan's (2000) definition of biography relates to works in which life-stories of renowned people in different areas are told in an evidence-based fashion. They also suggest that, biographies of leaders and important personalities are useful, as the life stories of such people with their different aspects set the pace for the individuals living in the same society.

The use of biographies as a teaching aid in social studies courses holds great importance in terms of provision of an enriched curriculum and achievement of the program objectives (Er \& Şahin, 2012). Regardless of how well the historical events of an era is taught on a chronological or logical basis, students can not perceive these events as realistic and concrete as the life of a person. In this context, biographies provide us with the opportunity to get a brief glimpse and a better grasp of an era from the eyes of a person living in that very period (Gençtürk, 2005). Life stories of great men, leaders and heroes give us insight into a specific era or trend, while they shed light on abstract and unsolved events that took place in that period (Er, 2005:13). By means of biographies, students get a grasp of how individuals and societies change the course of history; perceive the sequence, variability and persistence of historical events through establishing meaningful relations and connections between them (Fertig, 2005). Childhood and youth are, in a sense, the periods of reverence for heroes. In those years, children like to impersonate the lives of great men. In this sense, biographies can fulfill the need of children for role models to affectively guide and serve them as a model at the point of building their future (Kaymakcı \& Er, 2009). Also, biographies used in courses prepare children for future situations they are likely to encounter by telling other people's experienced struggles, challenges and fights for life (Er, 2010).

In addition to the benefits of using biographies as teaching materials in social studies courses, there are also other considerations that should be addressed. These can be briefly explained as follows. Biographies may sometimes fail to convey the complete sequence of events related to the subject. The way of addressing people in biographies may prevent children from perceiving the main subject and they may not be always attractive. It is usually easier to gather the events around people than gathering people around the events. Also, biographies used in courses should be in compliance with the topic, otherwise they cannot go beyond being a series of unconnected impressions in children's imaginations (Dewey, 1996; Ata, 1998; Sungu, 2002; Er, 2005; Er, 2008). One of the most important qualities sought in biographies is an unbiased and realistic narrative. In other words, well-written biographies are supposed to be well documented and knowledge based, while providing the reader with an unbiased narrative of real facts. Therefore, biographies should be written by people who are well-informed of / acquainted with the individual or who conducted a research on that person. In addition, biographies can be conveyed through story-telling, provided they stick to the facts. At this very point, author fictionalises the events and includes his/her personal remarks within the story. Particularly the stories prepared in narrative form and maintained at the student's level are more appealing for lower grade students (Demirel et al., 2010; Fırat, 2012; Karakuş, 2012; Dedeoğlu et al., 2013).

Several domestic and abroad research have been carried out on use of biography as a teaching material in social studies courses. These studies mainly focus on history and social studies teaching at primary and secondary school level. In this field, theoretical works of Warren (1992), McGowan \& Guzzetti (2003), Öztürk \& Otluoğlu (2003), Er (2009), Kaymakcı \& Er (2009), Oruç (2010), Kaymakcı (2013), Kaymakcı \& Er (2013) address the properties and types of biography, provide information as to how it should be used in social studies and history courses, and give an insight into its benefits and limitations. Applied studies, on the other hand, involving those of Öztürk \& Otluoğlu (2002), Er (2005), Gençtürk (2005), Er (2010), Oruç \& Erdem (2010), Erdem (2010), Kaya (2011), Er \& Şahin (2012), Yiğittir \& Er (2013), Yeşilbursa \& Sabanc1 (2013), İnan (2016), particularly lay emphasis on the biographic elements incorporated in social studies and history teaching programs and textbooks, their characteristics, opinions of students and teachers on use of biography, its influence on students' attitudes towards the courses and on their academic success, as well as its use as a tool in values education. In this respect, the absence of such works on use of biography at higher education level brought about the necessity to carry out the present research. Accordingly, this study was carried out for the particular course of science, technology and social change included in the social studies education undergraduate program, with a view to fill the research gap in literature and to provide guidance for researchers in their future studies. 


\subsection{Objective}

In this research, evaluation of opinions of social studies teacher candidates on use of biography in science, technology and social change course included in social studies education undergraduate program, was aimed. In this regard, answers to the following questions were sought:

- What are the opinions of social studies teacher candidates on the use of biography?

- Is there a statistically significant difference between the pretest and posttest results for opinions of social studies teacher candidates on use of biography in science, technology and social change course?

- Is there a significant difference between the pretest and posttest results for use of biography in science, technology and social change course on the basis of gender variable?

\section{Method}

\subsection{Research Model}

Evaluation of opinions of social studies teacher candidates on the use of biography in science, technology and social change course was aimed in the present study. Accordingly, exploratory sequential pattern as a mixed research pattern was applied for evaluation of both qualitative and quantitative data. This pattern gives precedence to gathering and analysis of research data. Researcher embarks on the second stage on the basis of these obtained results and accordingly tests and generalizes the primary results. Researcher afterwards explains how he/she has built the quantitative data on the qualitative data. (Creswell \& Plano Clark, 2014).

Single group pretest-posttest experimental pattern was used during the quantitative step. In this pattern, the effect of experimental procedure is tested by means of the operations on a single group. Dependent variable measurements of samples are obtained using pretest and posttest respectively before and after application using the same samples and measurement tools. This method does not involve randomness and matching. This pattern is also referred to as single factor intragroup or repetitive measurements pattern (Büyüköztürk et al., 2010).

\subsection{Study Group}

The study group consists of 49 students receiving education in Bartın University Faculty of Education Department of Primary Education Social Studies Teaching $2^{\text {nd }}$ grade as of 2015-2016 academic year. The study group was determined using purposive sampling method. This method was preferred considering the fact that the researcher is an employee of the said institution, and with a view to design a suitable research environment. Gender based distribution of the 2nd grade social studies students that participated in the research is given in Table 1.

Table 1. Gender Based Frequency and Percentage Distribution of Students

\begin{tabular}{lll}
\hline Gender & f & \% \\
\hline Female & 22 & 44,9 \\
\hline Male & 27 & 55,1 \\
\hline Total & $\mathbf{4 9}$ & $\mathbf{1 0 0}$ \\
\hline
\end{tabular}

As seen in Table 1, the participants consist of 22 female (44,9\%) and 27 male $(55,1 \%)$ students.

\subsection{Data Collection Tool}

"The Use of Biography in Social Studies Education Questionnaire", prepared as two parts by the researcher, was used to gather the quantitative research data. The students were asked their gender in the first part of the questionnaire. The second part includes items related with the use of biography in education. The likert type scale responses to the questionnaire items are as follows: "completely agree", "agree", "indecisive", "disagree", "completely disagree".

After consulting with an expert, preliminary application of the prepared "The Use of Biography in Social Studies Education Questionnaire" was performed on $2^{\text {nd }}$ grade social studies teaching students who were not involved in the study group. Following the preliminary application, some of the items were excluded and Cronbach's Alpha coefficient of the 40-items questionnaire was determined as 0,92. Item-based Cronbach's alpha distribution is given in Table 2. 
Table 2. Cronbach's Alpha Values of the Items of "The Use of Biography in Social Studies Education Questionnaire"

\begin{tabular}{llllll}
\hline Item & $\begin{array}{l}\text { Cronbach's } \\
\text { Alpha }\end{array}$ & Item & $\begin{array}{l}\text { Cronbach's } \\
\text { Alpha }\end{array}$ & Item & $\begin{array}{l}\text { Cronbach's } \\
\text { Alpha }\end{array}$ \\
\hline 1 &, 923 & 15 &, 918 & 29 &, 922 \\
2 &, 917 & 16 &, 919 & 30 &, 916 \\
3 &, 919 & 17 &, 919 & 31 &, 917 \\
4 &, 924 & 18 &, 916 & 32 &, 917 \\
5 &, 921 & 19 &, 917 & 33 &, 916 \\
6 &, 918 & 20 &, 918 & 34 &, 917 \\
7 &, 918 & 21 &, 921 & 35 &, 917 \\
8 &, 917 & 22 &, 916 & 36 &, 918 \\
9 &, 917 & 23 &, 916 & 37 &, 919 \\
10 &, 918 & 24 &, 921 & 38 &, 916 \\
11 &, 917 & 25 &, 920 & 39 &, 920 \\
12 &, 918 & 26 &, 919 & 40 &, 920 \\
\hline 13 &, 920 & 27 &, 920 & \multirow{2}{*}{ Cronbach's Alpha: ,92 } \\
\hline 14 &, 918 & 28 &, 918 & &
\end{tabular}

\subsection{Application Period}

In line with the research, the following stages were conducted during the application process in the science, technology and social change course.

- Following the validity and reliability studies, the questionnaire was applied as a pretest on 49 students comprising the study group.

- Science, technology and social change course was taught by the researcher using the traditional method in the first 7 weeks of the 14-weeks academic period.

- During the second 7 weeks period, each student chose a scientist related with the topics, prepared a biography and presented it in the classroom environment.

- Each of the prepared presentations was also prepared in poster form and exhibited at the end of the academic period in an exhibition called "Scientists: From Past to Present". Also, attendance to this exhibition by students and academic staff of faculty of education was ensured.

Biographies of the following scientists were prepared by social studies $2^{\text {nd }}$ grade students in science, technology and social change course:

- Lagari Hasan Çelebi
- Mimar Sinan
- Henry Martin Ford
- Thomas Edison
- Aydın Sayll
- Hulusi Behçet
- Albert Einstein
- El Cezeri
- Uluğ Bey
- El-Biruni
- Fuat Sezgin
- İbn El Heysem
- Cahit Arf
- El-Harezmi
- İbn-I Sina
- Kaşgarlı Mahmut
- Ömer Hayyam
- Blaise Pascal
- Katip Çelebi
- Erzurumlu İbrahim Hakkı
- İor İvanoviçSikorsky
- Yusuf Has Hacip
- İbn-İ Haldun
- Hezarfen Ahmet Çelebi
- Naima

\author{
- El İstahri \\ - El Battani \\ - Nizam-ı Mülk \\ - Piri Reis \\ - Farabi \\ - Abdulhamid İbn Türk \\ - Graham Bell \\ - Mahmut Gazi Yaşargil \\ - El-Mesudi \\ - Nasuriddin Tusi \\ - Charles Darwin \\ - Aziz Sancar \\ - Leonardo Da Vinci \\ - Oktay Sinanoğlu \\ - Enzo Ferrari \\ - El-Battani \\ - Benu Musa \\ - El-Razi \\ - Ibn Haldun \\ - Galileo \\ - Descartes \\ - Ali Kuş̧̧u \\ - Steve Jobs \\ - Newton
}


Following the application period, the questionnaire previously given to the participants were applied again as the post-test. The data, obtained from both tests, were comparatively analyzed to evaluate the effectiveness of the performed application.

Semi-structured interview form was used to gather the qualitative data of the research. In the first part of the interview form, which was prepared as three parts after consulting with an expert, a single question was asked to receive the opinions of students prior to the application. The first part of the questionnaire was applied prior to the application of pretest. The second part of the form involves a single question to receive the students' opinions and it was implemented in the middle of the application period. The last part of the form includes seven open-ended questions and it was implemented prior to the posttest.

\subsection{Data Analysis}

The quantitative data obtained from the used questionnaire were analyzed using SPSS software. Kolmogorov- Smirnov test was applied prior to the analysis as a means to determine whether the obtained data exhibit a normal distribution.

The results of the normality test applied on "The Use of Biography in Social Studies Education Questionnaire" are given in Table 3.

Table 3. The normality test results for "The Use of Biography in Social Studies Education Questionnaire"

\begin{tabular}{lllll}
\hline \multirow{2}{*}{ Questionnaire } & \multicolumn{3}{l}{ Kolmogorov-Smirnov ${ }^{\mathrm{a}}$} \\
\cline { 2 - 4 } & Statistic & $\mathrm{sd}$ & $\mathrm{p}$ \\
\hline $\begin{array}{l}\text { The Use of Biography in } \\
\text { Social Studies Education }\end{array}$ &, 143 & 49 &, $014^{*}$ \\
Questionnaire"
\end{tabular}

$* \mathrm{p}<.05$

As seen in Table 3, total scores of the questionnaire for use of biography in social studies education was not found to exhibit a normal distribution $(\mathrm{p}<.05)$. Since the groups did not show normal distribution, non-parametric tests were used. During data analysis:

- Frequency and percentage, among descriptive statistics, were used in the analysis of data from personal information (gender) part of the questionnaire.

- Dependent sample was used to determine whether a significant difference exists between the averages of pretest and posttest; and Wilcoxon signed-rank test, as a non-parametric test, was used since the groups did not have a normal distribution.

- Mann Whitney U-Test, among non-parametric tests, was used to determine if a significant gender-based difference occurs for the use of biography in science, technology and social change course, since there are two independent categories, and the groups do not show a statistically significant difference.

- Qualitative data were evaluated with descriptive analysis.

\section{Results}

The qualitative analysis results related with student opinions, as well as the pretest and posttest results of the application, implemented for the use of biography in social studies education: science, technology and social change course; the results obtained from the comparison of gender-based posttest results are given in this section.

\subsection{Qualitative Sub-dimension Results of the Research}

In this section, answers were sought for the questions included in the qualitative sub-dimension of the research.

Responses of social studies teacher candidates to the question: "What are the benefits of using biography in lessons?" in the application of "the use of biography in social studies education undergraduate program; science, technology and social change course" are given in Table 4.

Table 4. Distribution of the student responses to the question: "What are the benefits of using biography in lessons".

\begin{tabular}{ll}
\hline Opinions of Social Studies Teacher Candidates & f \\
\hline Establishing a link between the past and the present & 4 \\
Uncovering unknown personalities & 5 \\
Providing role models for students & 7 \\
Shedding light on the people's lives and the era they lived in & 10 \\
Ensuring permanent learning for the related topic & 14 \\
Rendering the course an interesting and enjoying activity & 9 \\
\hline
\end{tabular}

As seen in Table 4, students expressed their opinions on the use of biography in lessons in terms of its: ensuring 
permanent learning for the related ( $\mathrm{f}=14)$, shedding light on the people's lives and the era they lived in $(\mathrm{f}=10)$, rendering the course an interesting and enjoying activity topic $(\mathrm{f}=9)$, providing role models for students $(\mathrm{f}=7)$, uncovering unknown personalities ( $\mathrm{f}=5)$, establishing a link between the past and the present $(\mathrm{f}=4)$.

Some of the expressions of social studies teacher candidates as to the use of biography in courses are as follows:

S23: Students are provided with in-depth knowledge as to the person's life in addition to that specific era's properties.

S12: It primarily provides and event and person-oriented permanent learning.

Opinions of the social studies teacher candidates in response to the question: "What are the limitations of the use of biography in the courses?" in social studies education undergraduate program; science, technology and social change course biography application, are given in Table 5 .

Table 5. Distribution of the social studies teacher candidates' opinions in response to the question: "What are the limitations of the use of biography in courses?"

\begin{tabular}{ll}
\hline Opinions of Social Studies Teacher Candidates & f \\
\hline Long and knowledge-based biography forms are boring for students & 6 \\
Classroom and course conditions do not always conform with biography use & 4 \\
Biographic references lack objectivity and impartiality & 11 \\
Biographies fail to give insight into all subjects & 9 \\
Frequent use of biographies bore students & 7 \\
Insufficiently constructed biographies distract students & 6 \\
\hline
\end{tabular}

As seen in Table 5, opinions of social studies teacher candidates on limitations of biographies are: biographic references lack objectivity and impartiality ( $\mathrm{f}=11$ ), biographies fail to give insight into all subjects $(\mathrm{f}=9$ ), frequent use of biographies bore students ( $\mathrm{f}=7$ ), long and knowledge-based biography forms are boring for students $(\mathrm{f}=6)$, insufficiently constructed biographies distract students $(\mathrm{f}=6)$, and classroom and course conditions do not always conform with biography use ( $\mathrm{f}=4)$.

Some of the statements of social studies teacher candidates regarding the limitations of biographies used in courses are as follows:

S09: Biographies generally refer to the positive aspects of individuals; negative aspects should also be mentioned. Biographies therefore fail to convey the events from an objective point of view.

S34: Biographies do not necessarily shed light on the events and subjects regarding that era. This may prevent students to get a complete understanding of the course of event that took place in that specific era.

The opinions of students in response to the question: "What are the main differences between a biography based course and a non-biography based course?" as to the use of biography in social studies education undergraduate program; science, technology and social change course, are given in Table 6.

Table 6. Distribution of social studies teacher candidates' opinions in response to the question: "What are the main differences between a biography based course and a non-biography based course?"

\begin{tabular}{ll}
\hline Social Studies Teacher Candidates' Opinions & f \\
\hline Biography based courses provide a solid learning & 6 \\
Biography based courses are enjoyable and attractive & 20 \\
Subjects are taught in more detail with biography based courses & 5 \\
Biography based courses provide increased permanent learning & 13 \\
Biography based courses provide students with various role models & 4 \\
\hline
\end{tabular}

As seen in Table 6, the opinions of social studies teacher candidates on biography based courses and non-biography based courses are as follows: biography based courses are enjoyable and attractive $(\mathrm{f}=20)$, biography based courses provide increased permanent learning $(f=13)$, biography based courses provide a solid learning $(f=6)$, subjects are taught in more detail with biography based courses $(\mathrm{f}=5)$, biography based courses provide students with various role models $(\mathrm{f}=4)$

Some of the opinions of social studies teacher candidates on the differences between biography based courses and non-biography based courses are as follows:

S40: In my opinion biography based lessons are more amusing, fun and useful than non-biography based courses. Especially diverse knowledge on people's lives increases the attention and attendance of students.

S02: Conveyance of information on lives of socially prominent individuals with biographies using visual and auditory elements results in a more solid and permanent learning.

Opinions of social studies teacher candidates in response to the question: "Which methods did you follow while 
preparing biography based course activities?" as to the use of biography in social studies education undergraduate program; science, technology and social change course, are given in Table 7.

Table 7. Distribution of the social studies teacher candidates' opinions in response to the question: "Which methods did you follow while preparing biography based course activities?"

\begin{tabular}{ll}
\hline Opinions of Social Studies Teacher Candidates & f \\
\hline Teaching the biography so as to provide a role model for students & 10 \\
Aiming to increase permanence through frequent use of visuals & 8 \\
Focusing on the individual's studies and works while teaching biographies & 7 \\
Providing a consistent teaching by maintaining a chronological order & 6 \\
Using diverse references for providing a multidirectional learning & 15 \\
\hline
\end{tabular}

As seen in Table 7, opinions of social studies teacher candidates as to the methods they use while preparing the course activities for biography based lessons are as follows: using diverse references for providing a multidirectional learning $(\mathrm{f}=15)$, teaching the biography so as to provide a role model $(\mathrm{f}=10)$, timing to increase permanence through frequent use of visuals $(\mathrm{f}=8)$, focusing on the individual's studies and works while teaching biographies $(\mathrm{f}=7)$, providing a consistent teaching by maintaining a chronological order $(\mathrm{f}=6)$.

Some of the statements of social studies teacher candidates regarding the methods they used while preparing course activities for biography based courses are as follows:

S48: I attempted to teach the scientist, subject of the biography, after an in-depth investigation from different references and by revealing his/her unknown aspects.

S38: The life of the individual, subject of the biography, involved many virtues and merits that could make him/her a role model for other people. I, therefore, put particular emphasis on these aspects in the individual's biography.

The opinions of students in response to the question: "What are the main difficulties that you underwent while preparing activities for biography based courses?" as to the use of biography in social studies education undergraduate program; science, technology and social change course, are given in Table 8.

Table 8. Distribution of the teacher candidates" opinions in response to the question: "What are the main difficulties that you encounter while preparing activities for biography based courses?"

\begin{tabular}{ll}
\hline Opinions of Social Studies Teacher Candidates & f \\
\hline Difficulties in finding sufficient references & 5 \\
Inconsistencies among references & 11 \\
Lack of reliability and objectivity in references & 8 \\
Insufficient references as to the individual's works and visuals & 16 \\
No difficulties were encountered & 8 \\
\hline
\end{tabular}

As seen in Table 8, the difficulties encountered by social studies teacher candidates while preparing activities for biography based courses, are as follows: insufficient references as to the individual's works and visuals ( $\mathrm{f}=16$ ), inconsistencies among references $(\mathrm{f}=11)$, lack of reliability and objectivity in references $(\mathrm{f}=8)$, no difficulties were encountered ( $\mathrm{f}=8$ ), difficulties in finding sufficient references $(\mathrm{f}=5)$.

Some of the statements of social studies teacher candidates as to the difficulties they encounter while preparing activities for biography based courses are as follows:

S33: It was a challenging task to find the visuals of the individual, subject of the biography, as he/she lived in an early period.

S29: The biggest challenge was the literature review. The vast amount of details regarding the person and the lack of consistency among them made it hard to make a distinction between correct and false information.

Opinions of social studies teacher candidates in response to the question: "What are your reasons for choosing the individual, subject of your biography?" as to the use of biography in social studies education undergraduate program; science, technology and social change course, are given in Table 9.

Table 9. Distribution of social studies teacher candidates' opinions in response to the question: "What are your reasons for choosing the individual, subject of your biography?"

\begin{tabular}{ll}
\hline Opinions of Social Studies Teacher Candidates & f \\
\hline His/her interesting life & 14 \\
His/her under-recognized personality & 9 \\
His/her interesting field of occupation & 8 \\
His/her tremendous contributions to scientific world & 10 \\
His/her admirable aspects & 7 \\
\hline
\end{tabular}


As seen in Table 9, the reasons for social studies teacher candidates in choosing the individuals for their biographies are as follows: his/her interesting life $(\mathrm{f}=14)$, his/her tremendous contributions to scientific world ( $\mathrm{f}=10$ ), his/her under-recognized personality ( $\mathrm{f}=9$ ), his/her interesting field of occupation $(\mathrm{f}=8)$, his/her admirable aspects ( $\mathrm{f}=7$ )

Some of the statements of social studies teacher candidates as to their reasons in choosing individuals for their biographies are as follows:

S14: I chose Fuat Sezgin. I had read a beautiful book about him in my high school years. This book was about his works, tenacity and determination, which really impressed me. This is why I was always curious about his life.

S27: I chose Mimar Sinan. My reason for choosing him is his magnificent works in the Ottoman era, which have survived to this day and still serves humanity.

The opinions of social studies teacher candidates in response to the question: "What are your impressions prior to the application?" as to the use of biography in social studies education undergraduate program; science, technology and social change course, are given in Table 10.

Table 10. Distribution of the social studies teacher candidates' opinions in response to the question: "What are your impressions prior to the application regarding the use of biography in science, technology and social change course?"

\begin{tabular}{ll}
\hline Opinions of Social Studies Teacher Candidates & f \\
\hline Doubtful and feeling apprehension & 16 \\
Uncertainty and confused feelings & 8 \\
Feeling excited & 7 \\
Increased motivation & 11 \\
An opportunity to see our knowledge level as to the subject & 5 \\
\hline
\end{tabular}

As seen in Table 10 the impressions of social studies teacher candidates regarding the use of biography in science, technology and social change course prior to the application are as follows: doubtful and feeling apprehension ( $\mathrm{f}=16$ ), increased motivation ( $f=11$ ), uncertainty and confused feelings $(f=8)$, feeling excited $(f=7)$, an opportunity to see our knowledge level as to the subject $(\mathrm{f}=5)$.

Some of the statements by social studies teacher candidates regarding the use of biography in science, technology and social change course "prior to application" are as follow:

S18: I do not have much knowledge as to how the application will be implemented, which difficulties will be encountered and what am required to do. Also, this is the first time I am witnessing such an application in the course. Therefore I feel a little anxious prior to application.

S03: Initially I thought that the course would be boring and based on memorization. But then I was very glad to hear about such an activity. I think that this application will change the monotonous way in which the course is taught and it will be really useful.

The opinions of social studies teacher candidates in response to the question "What are your impressions regarding the use of biography in social studies education undergraduate program; science, technology and social change course, during the application?" are given in Table 11.

Table 11. Distribution of social studies teacher candidates' opinions in response to the question: "What are your impressions regarding the use of biography in science, technology and social change course, during the application?"

\begin{tabular}{ll}
\hline Opinions of Social Studies Teacher Candidates & f \\
\hline Excitement and gladness & 8 \\
Learning about new stuff & 13 \\
Undergoing various challenges & 10 \\
Interesting and amusing course of the lesson & 11 \\
Enjoyment & 6 \\
\hline
\end{tabular}

As seen in Table 11, the opinions of social studies teacher candidates in response to the question: "What are your impressions regarding the use of biography in science, technology and social change course, during the application?" are as follows: learning about new stuff $(\mathrm{f}=13)$, interesting and amusing course of the lesson ( $\mathrm{f}=11)$, undergoing various challenges ( $\mathrm{f}=10)$, excitement and gladness $(\mathrm{f}=8)$, enjoyment $(\mathrm{f}=6)$.

Some of the statements of social studies teacher candidates "during the application" regarding the use of biography in science, technology and social change course are as follows:

S22: I have received very different and new information about people that I did not know much about, which made me very glad.

S30: During the application, the efforts of my friends in preparation stage of their biographies resulted in a 
very fluently and amusingly taught course. I witnessed that most of my friends attended the course with utmost attention and excitement.

The opinions of social studies teacher candidates in response to the question: "What are your impressions regarding the use of biography in science, technology and social change course, after the application?" are given in Table 12.

Table 12. Distribution of social studies teacher candidates" opinions in response to the question: "What are your impressions regarding the use of biography in science, technology and social change course, after the application?"

\begin{tabular}{ll}
\hline Social Studies Teacher Candidates' Opinions & f \\
\hline Increased amusement and self confidence & 12 \\
Increased interest in the course & 8 \\
Gaining a new perspective & 5 \\
Its being useful and impressive & 9 \\
Gaining solid and permanent knowledge & 14 \\
\hline
\end{tabular}

As seen in Table 12, the opinions of social studies teacher candidates in response to the question: "What are your impressions regarding the use of biography in science, technology and social change course, after the application?", are as follows: gaining solid and permanent knowledge ( $\mathrm{f}=14)$, increased amusement and self-confidence $(\mathrm{f}=12)$, its being useful and impressive $(\mathrm{f}=9)$, increased interest in the course $(\mathrm{f}=8)$, gaining a new perspective $(\mathrm{f}=5)$.

Some of the statements of social studies teacher candidates regarding the use of biography in science, technology and social change course, "after the application" are as follows:

S43: I am so glad that the course was taught by the aid of biographies of scientists, because it was amusing and enjoyable, and we learned about the extent to which we can do with presentations. This made me really happy.

S07: I think we have done an excellent job with this application. The prepared posters and activities were successful and permanent. I intend to prepare such activities and materials in my teaching career.

\subsection{Quantitative Sub-dimension Results of the Research}

In this section, answers were sought for the questions included in the quantitative sub-dimension of the research.

Since the groups did not exhibit a normal distribution, Wilcoxon Signed Rank test was used to determine whether there is a statistically significant difference between the pretest and posttest results of the application performed for the use of biography in social studies program; science, technology and social change course. The test results for the use of biography in social studies undergraduate program; science, technology and social change course are given in Table 13.

Table 13. Pretest and Posttest Results of Wilcoxon Signed Rank Test for the Use of Biography in Social Studies Education Undergraduate Program; Science, Technology and Social Change Course

\begin{tabular}{|c|c|c|c|c|c|}
\hline $\begin{array}{l}\text { Pretest } \\
\text { Measurement-Posttest } \\
\text { Measurement }\end{array}$ & $\mathrm{N}$ & Rank Average & Rank Sum & $\mathrm{z}$ & $\mathrm{p}$ \\
\hline Negative ranks & 1 & 9,50 & 9,50 & $-5,999$ &, 000 \\
\hline Positive ranks & 48 & 25,32 & 1215,50 & & \\
\hline Ties & 0 & & & & \\
\hline
\end{tabular}

$\mathrm{p}<.05$

As seen in Table 13, a statistically significant different was observed between the pretest and posttest results of the application implemented for the use of biography in social studies education; science, technology and social change course $(z=-5,999, p<0,05)$. Positive inclination of the ranks (pretest measurement) in the scores indicate that the application for "the use of biography in social studies education undergraduate program; science, technology and social change course" has a significant influence.

Opinions of the students on the use of biography in social studies education undergraduate program; science, technology and social change course are given in Table 14.

Table 14. Mann Whitney U Test results of "The Use of Biography in Social Studies Education Undergraduate Program; Science, Technology and Social Change Course" based on the gender variable.

\begin{tabular}{llllll}
\hline Gender & $\mathrm{N}$ & Rank Average & Rank Sum & $\mathrm{U}$ & $\mathrm{p}$ \\
\hline Female & 22 & 26,48 & 582,50 & 264,500 & \multirow{2}{*}{513} \\
\hline Male & 27 & 23,80 & 642,50 & & \\
\hline
\end{tabular}


As shown in Table 14, there is no statistically significant difference between the opinions of female and male students on the use of biography in social studies education undergraduate program; science, technology and social change course $(U=264,500 ; p>.05)$.

\section{Discussion and Conclusions}

In the present study, which aimed to evaluate the opinions of social studies teacher candidates regarding the use of biography in social studies education undergraduate program; science, technology and social change course, the qualitative results related with the benefits of using biography indicate that, teacher candidates have favorable opinions regarding the application since it provides permanent learning and gives insight not only into the life of the individual, but also into that specific era. As proposed by Yalçın \& Aytaş (2005) and Fırat (2012), children are generally curious about the lives of people who achieved success in various fields and they are apt to identify themselves with those people. Biographies also provide children with information as to the individuals that fascinate them. Erdem (2010), Demircioğlu \& Tokdemir (2008), Zarnowski (2003) \& Maxim, (1999) stated in their works that, biography may be an extremely useful literary genre for equipping the students with knowledge, skills and values in social studies education. In their study, Kıymaz \& Ulutaş (2012) underlined the values and moralities, and they put particular emphasis on the need for highlighting the positive aspects of the individual, including the values such as industriousness, determination, benevolence and righteousness. As to the limitations of the use of biography in courses, teacher candidates are generally of the opinion that biographical references lack objectivity and impartiality, and that they are not sufficient for shedding light on all subjects. As suggested by Erdem (2010), biographies should not be limited with the life stories of individuals, and they should also cover the culture, social lives and events, as well as administration and other related issues regarding that specific era.

According to the results as to the differences between biography based and non-biography based courses, majority of teacher candidates find biography based courses more fun and attractive, and they also think that this increases permanent learning. This finding is in agreement with the results of Yeşilbursa \& Sabancı's study (2015) in which they stated that literary genres have a potential to increase permanent learning, and they could be used in increasing attendance and attract attention in the courses. Likewise, Oruç \& Erdem's (2010) results show that, the use of biography in social studies courses is likely to increase the positive impressions towards the course. In addition to these positive aspects, Firat (2012) pointed out the scarce number of biography samples written directly for children in the field of education. Zarnowski (1990) also stated that children are generally devoid of benefitting from biographical works and as a countermeasure they should be provided with effective guidance for studying and reading them.

The results as to the methods which could be followed while preparing activities for biography based courses indicate that, teacher candidates generally endeavor to teach the individual's biography using various references so as to provide a role model for students. In their study, findings of which is in agreement with the present research, Yiğittir \& $\operatorname{Er}(2013)$ state that, biographies have a potential to attract people's attention when the individual's life story is conveyed along with the unknown facts and different aspects of that person, and that, various awareness-raising activities can be performed in relation with the individuals that children perceive as "role models". The results related with the difficulties encountered while preparing activities for biography based course activities indicate that, the main drawbacks are insufficiency of the related references and the inconsistency among them. This finding is supported by the results of Kaya's (2011) study, which lays emphasis on the difficulties in providing a complete reflection of the individual with his/her all aspects, and the lack of objectivity arising from the author's tendency to include himself / herself in the story. Zengin (1994) also stated that, there are biographies with arguable accuracy due to insufficient documentation or intentional modifications, or arising from the sympathy or antipathy of the author for that specific person.

The results related with the reasons as to why the teacher candidates chose the people subject of their biographies indicate that, the main reasons are curiosity about that person's life, and the contributions made by that scientist. Er (2010) reported that, $4^{\text {th }}-8^{\text {th }}$ grade students' reasons for choosing prominent people are; their admirable personality (36.3\%), curiosity and reputation (33.9\%), service and success $(29.8 \%)$, which is in agreement with the findings of this research. In this context, Karakuş (2012) reported that, as a response to the question "who are the people who fascinate you most or that you take as a role model?", $42 \%$ of the students opted for Prophet Mohammad, Mustafa Kemal Atatürk and Mehmet Akif Ersoy. It should be noted that all of these people are well recognized with their deeds and moralities.

According to the teacher candidates' statements, they mostly felt anxiety and hesitation prior to application, they received new and diverse information during the application and they gained solid and permanent knowledge after the application. Accordingly, it can be concluded that, the hesitation felt prior to application increased the motivation of teacher candidates, the new information gained during application provided them with a different perspective regarding the use of biography, and the knowledge gained after the application increased the level of their self-confidence. As also 
suggested by Oruç \& Erdem (2010), biographies can be regarded as a teaching material in social studies education to make the course more attractive and to support teaching.

The quantitative results of the research indicate that there is a statistically significant difference between the pretest and posttest results of the implemented application. This further indicates that, the use of biography in science, technology and social change course has a significant influence. This finding is in agreement with the results of Erdem's (2010) study about biography-based teaching, in which a statistically significant difference was observed between the total gains of the students in the study group and the gain levels of the students in the control group. From a gender-based perspective, no statistically significant difference was found between the opinions of female and male students on use of biography in science, technology and social change course.

Consequently, biographies can be regarded as a multi-directional source to facilitate and support teaching, especially in today's world of diversified teaching methods and enriched material use. As stated by Er \& Şahin (2012), biographies should not be perceived only as teaching peoples' life stories. Biographies should also be regarded as pedagogically effective teaching tools that incorporate several tenets likely to serve as role models for people; involves character and values education; and increases permanent learning. Tanju (2013) proposed that, qualified biographies specifically prepared for children are likely to make a major contribution to their personal development through allowing them to learn about their own culture as well as the values of other cultures.

\subsection{Recommendations}

The following recommendations are proposed in line with the research results:

1. Diverse applications as to how biography can be used in "oral and written literature reviews course" can be implemented in social studies education undergraduate program.

2. Biographies can be effectively used in social studies education based on teacher and student opinions so as to support teaching.

3. Different types of scientific research can be carried out with a view to increase the effectiveness of biography use in the field of social studies.

4. Different activities such as exhibition, project, and poster preparation can be organized within the frame of related courses in social studies.

5. In social studies undergraduate education, students can be recommended to read the biographical works explaining the lives of people recognized with their lives and deeds, as a means for raising awaraness.

\section{Appendices}

Some of the posters prepared by social studies teacher candidates within the scope of the application carried out for use of biography in science, technology and social change course, are given below: 
Appendix: Poster 1
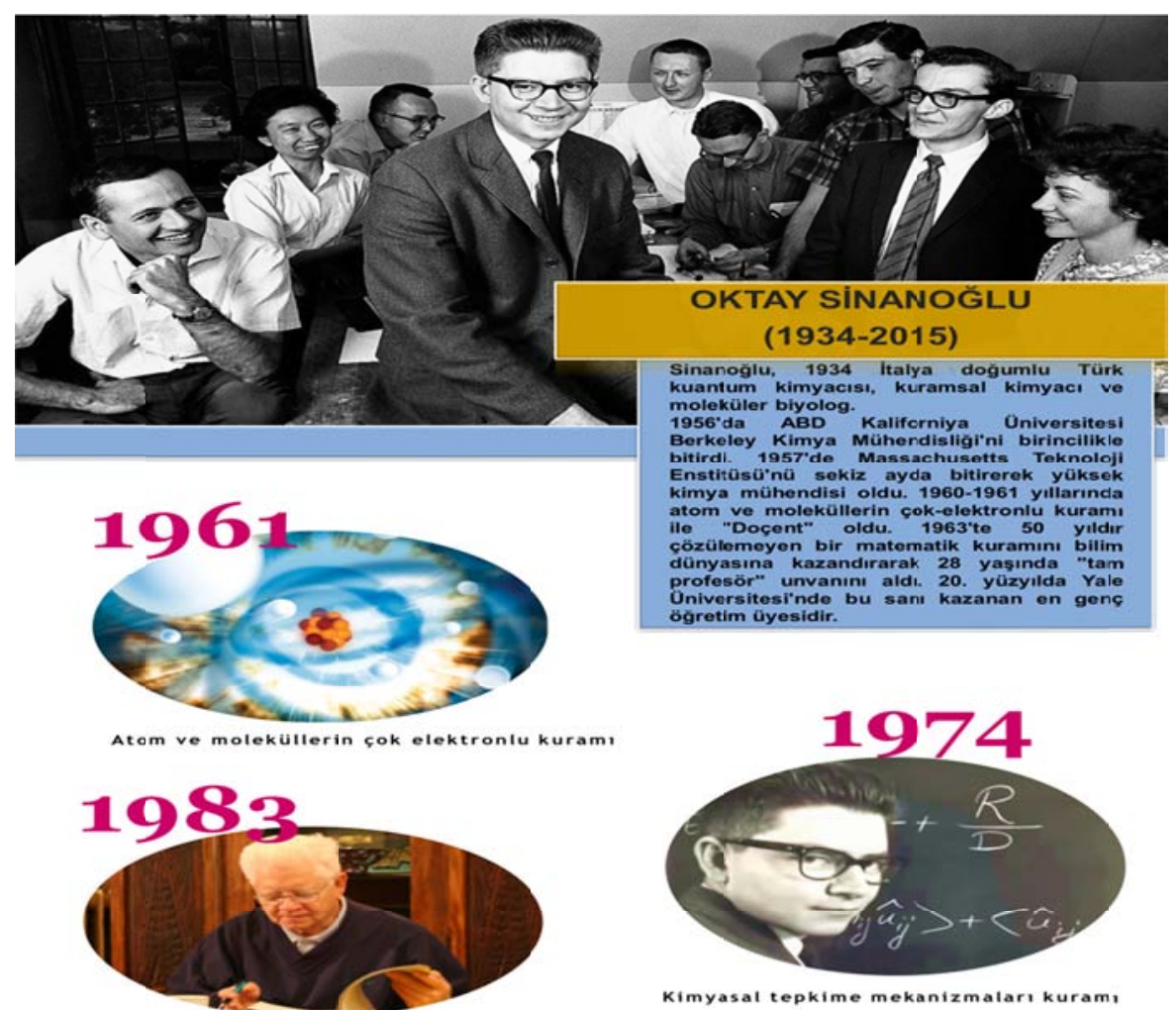

Degerlik kabuğu etkileșim kuramı

Pznar Durgut

Appendix: Poster 2

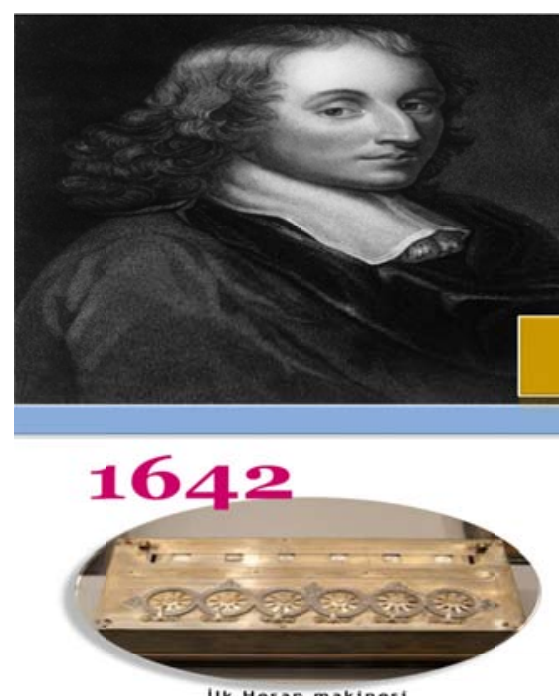

lik Hesap makinesi

(Vergi memuru babasinin isini kolaylasmak

\section{9}

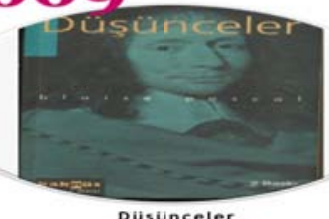

Düsunceler

Tanriy tanima yolunda yazd
kitap haline getiritmistir.)

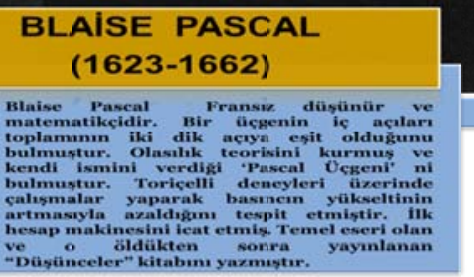

\section{3}

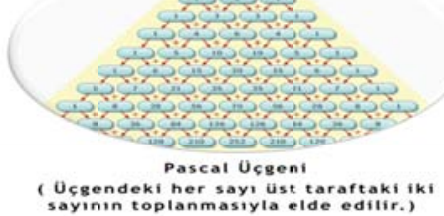

( Ocgendeki her sayi ust taraftaki iki
sayinin toplanmasiyla elde edilir.) 
Appendix: Poster 3
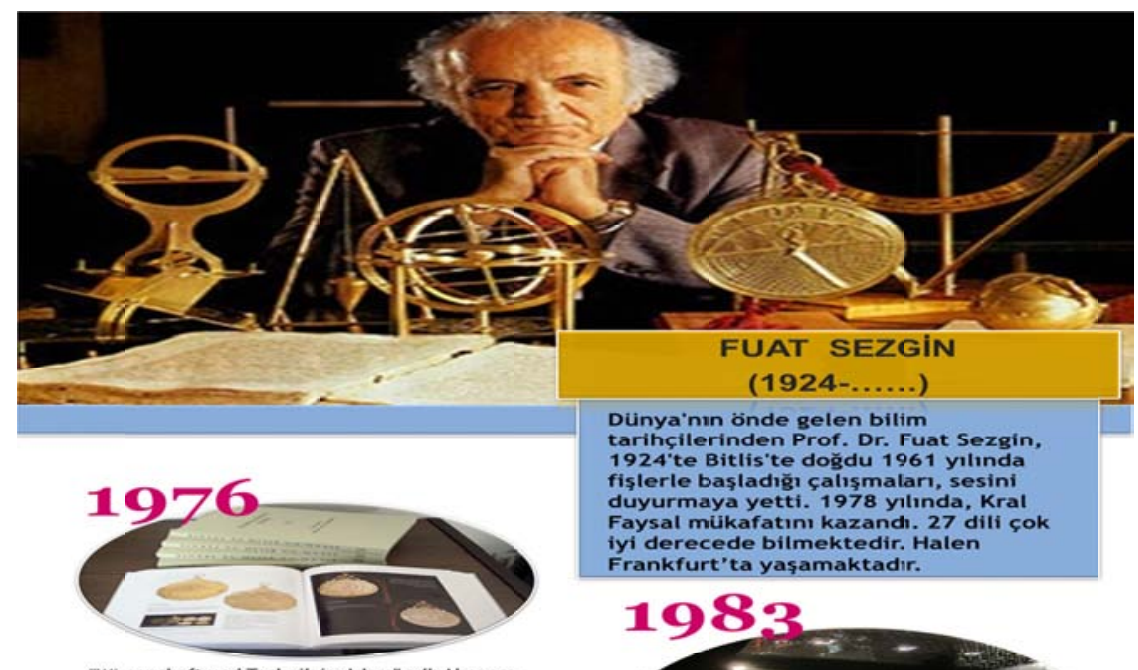

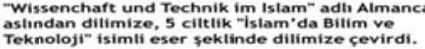
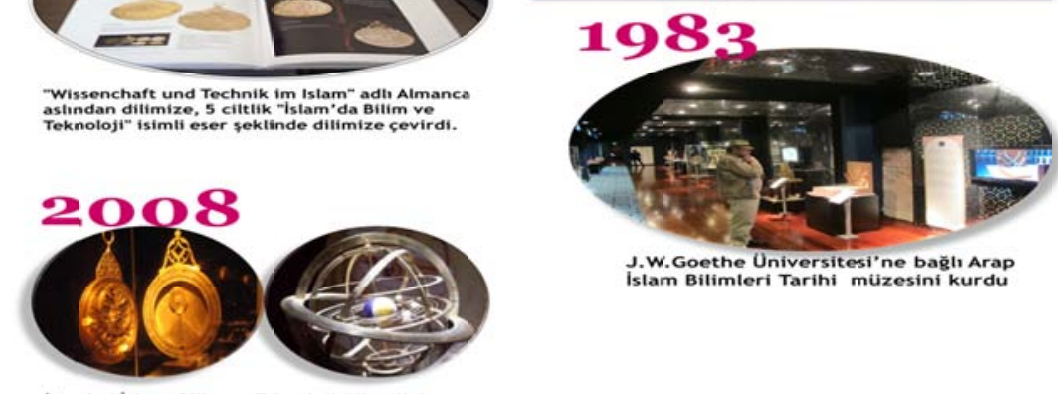

J.W. Goethe Universitesi' ne bağtı Arap
Islam Bilimleri Tarihi müzesini kurdu

istanbul islam, Bilim ve Teknoloji Mijzesi'nin açilmasinda bóncu rol oynamistır.

YUSUF YARĞL

Appendix: Poster 4
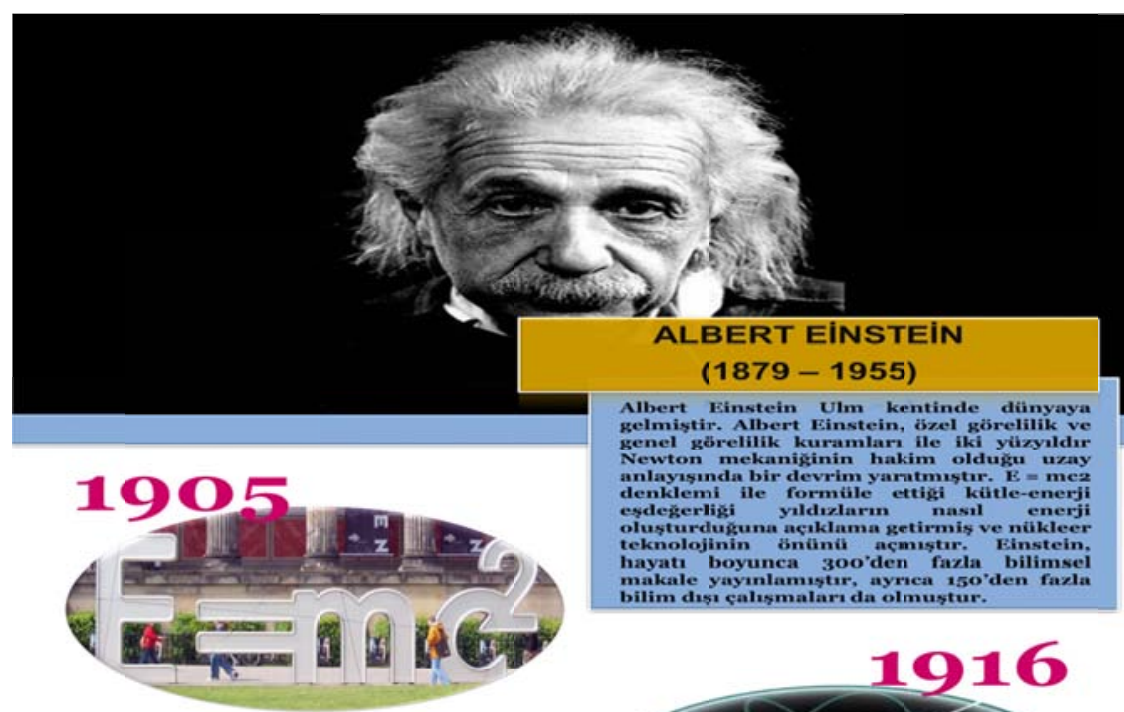

Fizikte Kutle-Enerji Esitili
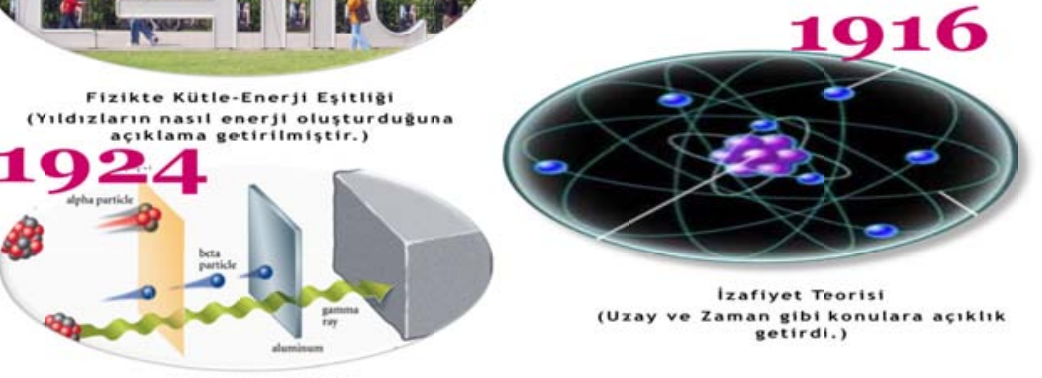

Fotoelektrik Etki Fotoelektrik Etki gostermistir., 


\section{References}

Ata, B. (1998). John Dewey and History Teaching in Turkish Primary Education (1923- 1930). Symposium on Atatürk's Targets After Proclamation of the Republic. İzmit: Kocaeli University and Atatürk Research Center, 5777.

Barth, J. L., \& Demirtaş, A. (1997). Social studies teaching in primary education, reference units. Ankara: YÖK/World Bank, National Education Development Project.

Büyüköztürk, Ş., Kılıç, Ç. E., Akgün, Ö. E., Karadeniz, Ş., \& Demirel, F. (2010). Scientific Research Methods (6.edition). Ankara: Pegem Publication.

Can, G., Yaşar, Ş., \& Sözer, E. (1998). Social Studies Teaching, Eskişehir: Anadolu University Publications.

Creswell, J.W., \& Plano, C., \& Vicki, L. (2014). Designing and Conducting Mixed Methods Research, Translation: Yüksel Dede ve\& Selçuk Beşir Demir, Ankara: Anı Publication.

Dedeoğlu, H., Ulusoy, M., \& Alıcı, M. (2013). A Content Analysis on the Biographical Books Prepared for Children. Hacettepe University Faculty of Education Journal, 28(2), 116-131.

Demir, S. B., \& Akengin, H. (2011). Social Studies Teaching Using Storytelling. Ankara: Pegem Academy.

Demircioğlu, İ. H., \& Tokdemir, A. (2008). History teaching in the course of establishment of values: Objective, function and content. Journal of Values Education, 6(15), 69-88.

Demirel, Ş. et al. (2010). Children's Literature via Literary Texts. Ankara: Pegem Academy Publications

Dewey, J. (1996). Democracy and Education (Translation: M. Salih Otaran). İstanbul: Başarı Publication.

Er, H. (2005). Biography teaching in social studies lesson; The analysis of (Atatük's life) articles and a new design. Gazi University Social Studies Teaching Department. Unpublished Master's Thesis, Ankara.

Er, H. (2008). How should primary education students be taught Atatürk's life within the scope of biography teaching in social studies education? International Symposium on Social Studies Education Proceedings Book. Çanakkale: ÇOMÜ Faculty of Education, 388-394.

Er, H. (2009). Biography Teaching in Social Studies Education, Gazi Faculty of Education Journal, (In memory of Reşat Genç) Special Issue, 29, 1546-1557.

Er, H. (2010). Primary Education Students' Opinions on the Use of "Biography" within the Scope of Social Studies Education”. Gazi University, Institute of Educational Sciences, Unpublished Doctorate Thesis, Ankara.

Er, H., \& Şahin, M. (2012). Students' opinions on the use of "biography" in social studies courses. The Journal of Turkish Educational Sciences, 10(1), 75-96.

Erdem, R. (2010). The use of biography in social studies teaching. Niğde University, Institute of Social Studies. Unpublished Master's thesis, Niğde.

Fertig, G. (2005). Teaching Elementary Students How to Interpret the Past. The Social Studies, 91(1), $2-8$. https://doi.org/10.3200/TSSS.96.1.2-8

Firat, H. (2012). Place Of Children Literature In Turkish Education: The Sample Of Biography Muğla Sitkı Koçman University Institute of Social Studies Journal, Fall, 29.

Fredericks, A. D. (2007). Much more social studies through children's literature: A collaborative approach. Westport, CT: Teacher Ideas Press.

Gençtürk, M. (2005). Use of Biography in History Teaching. Gazi University Institute of Educational Sciences. Unpublished Master's Thesis, Ankara.

Gültekin, M. (1999). Alternative Curriculum Models For Second Level of Basic Education.. Eskişehir: Anadolu University Publications.

İnan, S. (2016). The Psycho-Biographies In Historiography: From Good Examples To Determining Research Method. Turkish History Education Journal, Fall 5(2), 491-514.

Karakuş, N. (2012). Asım's Generation, Influence To Today And Educational Values. Journal of Language and Literature Studies, 6, 231-247.

Karakuş, N. (2012). Use of source text in Turkish teaching. Ankara: Pegem Academy Publication.

Kaya, A. (2011). Contribution of Biographic Works to History Teaching and Evaluation of the Period from the Second Constitutional Monarchy to the Republic. Dokuz Eylül University, Institute of Educational Sciences. Unpublished Master's Thesis, İzmir. 
Kaymakc1, S. (2013). The Usage Situation of Oral and Written Literary Works in Social Studies Textbooks. Dicle University Ziya Gökalp Faculty of Education Journal, 20, 230-255.

Kaymakc1, S., \& Er, H. (2009). The Use of Biography in Social Studies Teaching. Social Studies Teaching. Safran, M. (Ed.), Ankara: Pegema Academy.

Kaymakc1, S., \& Er, H. (2013). The Usage of Biography in Social Studies Curricula and Textbooks. Mehmet Akif Ersoy University Faculty of Education Journal, 13(25), 198-224.

Kıymaz, M. S., \& Ulutaş, A. (2012). Biographies In Aspect of The Values It Conducts: The Case of İleri Yavrutürk Magazine. Studies on Turkish Education-Teaching. Ankara: Pegem Academy Publications.

Maxim, G. W. (1999). Social studies and the elementary school child. New Jersey: Prentice Hall.

McGowan, T., \& Guzzetti, B. (2003). Using a Literature-Based Approach to Teaching Social Studies (Translation: Doğanay, A.). Çukurova University Faculty of Education Journal, 11(11), 35-44.

Oğuzkan, F. (2000). Children's Literature, Ankara: Anı Publication.

Oruç, Ş. (2010). Biography in history Teaching. M. Safran (Ed.), How to teach history? İstanbul: Yeni İnsan Press, 230-235.

Oruç, Ş., \& Erdem, R. (2010). Effect of biography usage in social studies teaching on students' attitudes towards social studies courses. Selçuk University Ahmet Keleşoğlu Faculty of Education Journal, 30, 215-229.

Öztürk, C. (2007). Social studies: An interdisciplinary approach to social life. Social Studies Teaching; a constructive approach. C. Öztürk (Editor). Ankara: Pegem Academy Publications.

Öztürk, C., \& Otluoğlu, R. (2002). The Effect Of Using Literary Materials To Acquire Affective Behaviors In Social Studies Teaching. İstanbul: Marmara U. Atatürk Faculty of Education Journal of Educational Sciences. Issue:15.

Öztürk, C., \& Otluoğlu, R. (2003). Literary Works and Written Materials in Social Studies Teaching. Pegema Publication, Ankara.

Parke, C. N. (1996). Biography: Writing Lives. New York, NU: Twayne.

Sungu, İ. (2002). On History Teaching (Translation: Bahri Ata). National Education, Issue: 153-154, Ankara: MEB. Press., 52-59.

Tanju, E. H. (2013). Children's Literature as a Literary Genre, Gönen, M. (Ed.). Children's Literature, (93-158). Ankara: Eğiten Kitap.

Taşdelen, V. (2006). Biography: A Journey to the Other. National Education Journal. Issue:172 Fall

Warren, A. K. (1992). Biography and Autobiography in the Teaching of History and Social Studies. Teaching Innovations column in the Perspectives, American Historical Association. http://www.historians.org/perspectives/issues/1992 web sitesinden 25.08 .2016 adresinden alınmıştır

Yalçın, A., \& Aytaş, G. (2005). Children's Literature. Ankara: Akçağ Publications.

Yeşilbursa, C. C., \& Sabancı, O. (2015). Pre-Service Social Studies Teachers' Views on Using Of Literary Works in Social Studies Teaching. Mehmet Akif Ersoy University Faculty of Education Journal, 36, 19-33

Yiğittir, S., \& Er, H. (2013). The use of biography for values education in social studies course National Education Journal, 200, 200-219.

Zarnowski, M. (1990). Learning about biographies: a reading-and-writing approach for children. IL:Urbana.

Zarnowski, M. (2003). History makers: A questioning approach to reading \& writing biographies. Portsmouth, NH: Heinemann.

Zengin, B. (1994). Biography in German and Turkish Literature and biographies of Stefan Zweig's Nietzsche and Hölderlin Kleis; Abdülhak Şinasi Hisar's biography of Ahmed Haşim. Ankara University, Institute of Social Studies. Unpublished Doctoral Thesis, Ankara.

\section{Copyrights}

Copyright for this article is retained by the author(s), with first publication rights granted to the journal.

This is an open-access article distributed under the terms and conditions of the Creative Commons Attribution license which permits unrestricted use, distribution, and reproduction in any medium, provided the original work is properly cited. 